УДК 349.41

DOI https:/ / doi.org/10.32837/yuv.v0i2.1736

\author{
О. Гулкевич, \\ аспірантка кафедри соціального права \\ Львівського національного університету імені Івана Франка
}

\title{
ПРАВОВИЙ РЕЖИМ ЗЕМЕЛЬ ІСТОРИКО-КУЛЬТУРНОГО ПРИЗНАЧЕННЯ
}

Одним із напрямів реалізації Концепції державної політики реформування сфери охорони нерухомої культурної спадщини є створення ефективної системи контролю над станом охорони і збереження об'єктів культурної спадщини, захисту традиційного характеру шляхом запровадження інноваційних підходів до охорони земель, на яких розташовані пам'ятки культурної спадщини, їх комплекси (ансамблі), історико-культурні заповідники, історико-культурні заповідні територіі, охоронювані археологічні території, музё̈ просто неба, меморіальні музеї-садиби, тобто земель історико-культурного призначення [1]. На території України знаходиться близько 130 тис об'єктів культурної спадщини, які перебувають на державному обліку, 3 них 9562 пам'ятки, внесені до Державного реєстру нерухомих пам'яток України та шість унікальних культурних об'єктів, включених до Списку всесвітньої спадщини ЮНЕСКО. До Списку історичних населених місць України, відповідно до Постанови Кабінету Міністрів України від 26.07.01 № 878, включено 401 населене місце.

За таких умов особливої уваги набуває питання правового режиму земель історико-культурного призначення, чіткого визначення його змісту для подальших наукових досліджень, пошуків найкращих практик використання та охорони земель історико-культурного призначення.

Проблемам визначення поняття правового режиму, а також аналізу правового режиму земель та окремих їх категорій присвячено праці багатьох учених. Зокрема, можна виділити роботи В.І. Андрейцева, О.В. Бевз, О.В. Донець, Д.Д. Коссе, Н.I. Краснова, О.I. Крассова, П.Ф. Кулинича, А.В. Малька, M.I. Матузова, А.M. Мірошниченка, В.I. Семчика, I.О. Соколової, Н.І. Титової, Л.В. Томаша та ін.

«Правовий режим» як юридична категорія неодноразово вживається в українському законодавстві та досліджується науковцями. Поширеність цього поняття у правовій доктрині зумовлена тим, що воно допомагає лаконічно і влучно виразити комплекс правових засобів, що застосовуються у регулюванні суспільних відносин [2, с. 20]. Переважна більшість науковців визначає правовий режим як особливий порядок правового регулювання. Однак у нормативно-правових актах немає єдиного визначення та розуміння цього поняття.

Для визначення поняття «правовий режим земель історико-культурного призначення» доцільно взяти за основу загальне поняття правового режиму як юридичної категорії. Детальне визначення наводять Е.Ф. Шамсунова та Л.В. Томаш: «Правовий режим - це особливий порядок законодавчого врегулювання діяльності, дій чи поведінки фізичних і юридичних осіб у різних сферах суспільних відносин або на певних об'єктах, який охоплює встановлення механізму забезпечення фактичної реалізації системи стимулів, нормативів, гарантій, заборон, зобов'язань, обмежень, а також їх компетентне виконання, застосування заходів примусу 
і притягнення винних до відповідальності» $[3$, с. $24 ; 4$, с. 25$]$.

Правовий режим, що визначається нормативно-правовими актами, має на меті встановлення порядку діяльності суб'єктів щодо певних об'єктів для врегулювання суспільних відносин, що виникають. Як слушно стверджує Л. Томаш, концепція правового режиму має як теоретичне, так і практичне значення, адже однією з його особливостей $€$ те, що він виражає нерозривний зв'язок правової форми і змісту відносин, які регулюються.

Для науки це проявляється у можливості побачити глибину правого регулювання та права у цілому. Законодавцю концепція правового режиму дає змогу створити для певних суспільних відносин особливе регулювання, поклавши в основу необхідне поєднання юридичних засобів. У правозастосовній та правоохоронній діяльності - застосовувати нормативно-правові акти, забезпечувати контроль і нагляд законної дії механізмів реалізації [4, с. 25]. Таким чином, концепція правового режиму $€$ важливою та вкрай необхідною на всіх етапах праворозуміння та правозастосування.

Представники науки земельного права досліджували питання правового режиму земель загалом та окремих іï категорій. Так, на думку Н. Титової, правовий режим земель - це сукупність правових норм, що встановлюють певний порядок землекористування певних видів. Окрім цього, вчена стверджує, що для правового режиму важливим $€$ й наслідки здійснення правового регулювання [5, с. 65].

B.I. Андрейцев пропонує під правовим режимом земель розуміти встановлений нормативно-правовий порядок, який визначає поведінку суб'єктів земельних правовідносин щодо земель, земельних ділянок як щодо об'єктів права власності, управління, користування, відтворення, збереження та охорони 3 метою їх раціонального (економного й ефективного) використання i задоволення різноманітних потреб заінтересованих осіб, захисту їхніх земельних прав [6, с. 158].

B.I. Семчик та П.Ф. Кулинич розглядають правовий режим земель як установлений правовими нормами порядок та умови їх набуття у власність чи користування, зміни і припинення права власності, порядок та умови використання відповідно до цільового призначення, правової охорони земель і відповідальності за порушення земельних прав і земельного законодавства та як установлені правовими нормами право власності і користування земельними ділянками [7, с. 72]. Ураховуючи ці підходи до визначення правового режиму земель, можна зробити висновок, що правовий режим земель - це встановлений правовими нормами порядок поведінки по відношенню до цих земель [8, с. 91].

Водночас існує диференціація правових режимів залежно від того, стосовно яких саме земель вони встановлені. У ст. 19 Земельного кодексу України як самостійну категорію виділено землі історико-культурного призначення. Як й інші категорії земель, землі історико-культурного призначення мають особливий правовий режим (ч. 2 ст. 18 ЗК України). Доктринальне визначення правового режиму земель історико-культурного призначення дає Л. Бондар. Він виділяє загальний та спеціальний правові режими земель історико-культурного призначення. Під першим мається на увазі порядок поведінки суб'єктів правовідносин із приводу їх використання. Спеціальний правовий режим стосується земельних ділянок, що мають різні види цільового призначення у межах категорій земель історико-культурного призначення [9, с. 297]. Варто було б назвати ці види правового режиму дещо інакше, оскільки, на нашу думку, загальний правовий режим установлюється для всіх земель, а окремі категорії земель мають особливий правовий режим (ст. 18 3К України). Окрім того, згадані визначення є загальними та не розкривають специфіку правового 
режиму саме земель історико-культурного призначення.

У ст. 34 ЗУ «Про охорону культурної спадщини» вказано, що землі, на яких розташовані пам'ятки, історико-культурні заповідники, історико-культурні заповідні території, охоронювані археологічні територіі, належать до земель історико-культурного призначення. У Земельному кодексі це визначення дещо відрізняється: відповідно до ст. 53 3К України, до земель історико-культурного призначення належать землі, на яких розташовані пам'ятки культурної спадщини, їх комплекси (ансамблі), історико-культурні заповідники, історико-культурні заповідні території, охоронювані археологічні території, музеї просто неба, меморіальні музеї-садиби. Обидві норми з'явилися у законодавстві одночасно під час прийняття Закону України «Про внесення змін до деяких законодавчих актів України щодо охорони культурної спадщини».

Проаналізувавши приписи Концепції державної політики реформування сфери охорони нерухомої культурної спадщини, можна зробити висновок, що відповідальні органи у своїй діяльності використовують норму Земельного кодексу.

Окрім того, відповідно до ч. 2 ст. 34 ЗУ «Про охорону культурної спадщини», встановлення зон охорони пам'яток та затвердження меж історичних ареалів населених місць не може бути підставою для примусового вилучення 3 володіння (користування) земельних ділянок у юридичних та фізичних осіб за умов дотримання землевласниками та землекористувачами правил використання земель історико-культурного призначення. Зі змісту цієї норми стає зрозуміло, що зони охорони та історичні ареали населених місць не відносять до категорії земель історико-культурного призначення. Відповідно до ч. 1 ст. 32 ЗУ «Про охорону культурної спадщини», межі та режими використання зон охорони пам'яток визначаються відповідною науково-проєктною документацією і затверджуються від- повідним органом охорони культурної спадщини. У ч. 3 ст. 32 ЗУ «Про охорону культурної спадщини» вказано, що межі та режими використання історичних ареалів населених місць, обмеження господарської діяльності на територіях історичних ареалів населених місць визначаються у порядку, встановленому Кабінетом Міністрів України, відповідною науково-проєктною документацією, яка затверджується центральним органом виконавчої влади, що забезпечує формування державної політики у сфері охорони культурної спадщини або уповноваженими ним органами охорони культурної спадщини (ч. 3 ст. 32 ЗУ «Про охорону культурної спадщини»). Уважаємо, що правовий режим охоронних зон та історичних ареалів міст має спільні елементи з правовим режимом земель історико-культурного призначення, однак не $є$ тотожними.

Як слушно зазначає О. Бевз, історичний ареал населеного місця має затверджені межі й особливий правовий режим використання та охорони. На думку вченої, правовий режим земель історичних ареалів населених місць - це встановлений нормами права специфічний порядок регулювання відносин, спрямований на охорону земель історичних ареалів населених місць під час їх використання на різних правових титулах та в процесі управління у сфері використання та охорони таких земель із метою забезпечення історичного характеру середовища населеного пункту та збереження об'єктів культурної спадщини, що формують ареал [11, с. 7].

Землі, на яких розміщені охоронювані археологічні території, належать до земель історико-культурного призначення. Отже, на них поширюється притаманний цій категорії земель правовий режим. Відповідно до ст. 31 ЗУ «Про охорону культурної спадщини», топографічно визначені території чи водні об'єкти, в яких містяться об'єкти культурної спадщини або можлива їх наявність, за поданням відповідного органу охорони культурної спадщини можуть оголошуватися рішенням цен- 
трального органу виконавчої влади, що реалізує державну політику у сфері охорони культурної спадщини охоронюваними археологічними територіями на обмежений або необмежений строк у порядку, визначеному Кабінетом Міністрів України. Правовий режим охоронюваної археологічної території визначається центральним органом виконавчої влади, що забезпечує формування державної політики у сфері охорони культурної спадщини. Тож охоронюваним археологічним територіям як землям притаманний правовий режим земель історико-культурного призначення, а як комплексній юридичній категорії - власний правовий режим. На разі порядок оголошення територій охоронюваними археологічними територіями не затверджено й немає жодного рішення про присвоєння такого статусу.

Режим використання земель історико-культурного призначення встановлено не лише Земельним кодексом, а й законодавством про охорону культурної спадщини, зокрема Законом України «Про охорону культурної спадщини». Основною кваліфікуючою ознакою цієї категорії земель є розміщення на них об'єктів культурної спадщини. Цільове призначення таких земель полягає в їх використанні для збереження предмета охорони пам'ятки.

Як слушно зазначає О. Бевз, правовий режим земель історико-культурного призначення пов'язаний і певною мірою визначається правовим режимом об'єкта культурної спадщини, що там знаходиться. Такий висновок можна зробити з того, що ЗК України визначає склад земель історико-культурного призначення через перелік об'єктів, які знаходяться на даних землях [11, с. 55].

Окрім того, відповідно до ст. 1 Закону України «Про Державний земельний кадастр», об'єкт культурної спадщини $€$ режимоутворюючим об'єктом, тобто об'єктом природного або штучного походження, під яким та/або навколо якого у зв'язку з його природними або набутими властивостями згідно із зако- ном встановлюються обмеження у використанні земель. Це також указує на нерозривний зв'язок правового режиму об'єкта культурної спадщини та земель історико-культурного призначення. Однак не варто ототожнювати ці правові режими, оскільки не всі питання щодо використання, збереження та охорони об'єкта культурної спадщини пов'язані із земельною ділянкою.

Відповідно до ст. ст. 4-6 ЗУ «Про охорону культурної спадщини», управління цією категорією земель здійснюють спеціальні органи. Частково розподіл повноважень між органами залежить від категорії пам'ятки: національного чи місцевого значення. Відповідно до ст. 4 ЗУ «Про охорону культурної спадщини», Кабінет Міністрів України приймає рішення щодо занесення об'єктів культурної спадщини національного значення до Державного реєстру нерухомих пам'яток Украіни та надає дозволи на переміщення (перенесення) пам'яток національного значення. Так, до повноважень центрального органу виконавчої влади, що забезпечує формування та реалізацію державної політики у сфері охорони культурної спадщини (Міністерство культури та інформаційної політики України), належать внесення до реєстру пам'яток місцевого значення забезпечення дотримання режиму використання пам'яток, їніх територій, зон охорони, надання дозволів на проведення земляних робіт, погодження документації із землеустрою тощо.

Відповідно до ст. 6 ЗУ «Про охорону культурної спадщини», визначення меж територій пам'яток місцевого значення та затвердження їхніх зон охорони та встановлення режиму використання пам'яток місцевого значення, іхніх територій, зон охорони належать до повноважень органу виконавчої влади Автономної Республіки Крим, органів охорони культурної спадщини обласних, Київської та Севастопольської міських державних адміністрацій.

Законом установлено й обмеження щодо суб'єктного складу у правовід- 
носинах, що виникають щодо земель історико-культурного призначення. Відповідно до ст. 54. 3К України, землі історико-культурного призначення можуть перебувати у державній, комунальній та приватній власності. У ЗУ «Про охорону культурної спадщини» та ЗУ «Про Перелік пам'яток культурної спадщини, що не підлягають приватизації» деталізовано вищезгадану норму Земельного кодексу та визначено перелік об’єктів, що не підлягають приватизаціі.

Згідно зі ст. 17 ЗУ «Про охорону культурної спадщини», пам'ятка, крім пам'ятки археології, може перебувати у державній, комунальній або приватній власності. Суб'єкти права власності на пам'ятку визначаються згідно iз законом. Землі, на яких розташовані пам'ятки археології, перебувають у державній власності або вилучаються (викуповуються) у державну власність в установленому законом порядку за винятком земельних ділянок, на яких розташовуються пам'ятки археології поля давніх битв. Окрім того, відповідно до Закону України «Про Перелік пам'яток культурної спадщини, що не підлягають приватизації», приватизація деяких пам'яток культурної спадщини заборонена. Ураховуючи припис ст. 120 ЗК України, у якому йдеться про перехід права на земельну ділянку в разі набуття права на жилий будинок, будівлю або споруду, можна зробити висновок про неможливість передачі у приватну власність відповідних земельних ділянок.

Відповідно до п. «в» ч. 4 ст. 83 3К України, до земель комунальної власності, які не можуть передаватися у приватну власність, належать землі під об'єктами природно-заповідного фонду, історико-культурного та оздоровчого призначення, що мають особливу екологічну, оздоровчу, наукову, естетичну та історико-культурну цінність, якщо інше не передбачено законом. Схожа норма міститься у п. «г» ч. 4 ст. 84 3K України, де таке ж правило застосовується щодо земель державної влас- ності. Законодавство не визначає, які саме землі історико-культурного призначення мають таку особливу цінність і не можуть передаватися у приватну власність. О. Донець зазначає, що особлива цінність притаманна пам'яткам національного значення, тож, імовірно, й земельним ділянкам під ними. Однак це не є вирішенням проблеми, й існує потреба формування чіткого переліку земель виключної державної та комунальної власності [12, с. 81]. Більше того, відповідно до нового Порядку визначення категорій пам'яток, затвердженого Постановою Кабінету Міністрів України від 22 травня 2019 р. № 452, ознака «особлива цінність» більше не застосовується ні до пам'яток національного, ні до пам'яток місцевого значення.

Для забезпечення режиму охорони пам'яток, у тому числі й режиму використання відповідної території, ст. 23 ЗУ «Про охорону культурної спадщини» передбачено укладення охоронних договорів на пам'ятки культурної спадщини. Тож юридична чи фізична особа не пізніше ніж через один місяць від отримання пам'ятки у власність чи користування зобов'язана укласти охоронний договір, у якому буде визначатися режим використання пам'ятки та території, на якій вона розміщується. Порядок укладання охоронних договорів та їхні типові форми затверджено Постановою Кабінету Міністрів України від 28 грудня 2001 р. № 1768. В охоронному договорі зазначаються особливості режиму використання пам'ятки, види і терміни виконання робіт з упорядкування ї території, інших заходів, необхідність яких визначається відповідним органом охорони культурної спадщини.

Охоронний договір укладається з відповідним органом охорони культурної спадщини, який має належний обсяг повноважень. Слід звернути увагу на те, що договір може бути підписаний лише після погодження із центральним органом виконавчої влади, що забезпечує формування та реалізацію держав- 
ної політики у сфері охорони культурної спадщини.

Загалом в Україні охоронні договори укладені для 49103 пам'яток, що становить лише $35 \%$ випадків від загальної кількості (140 372 пам'ятки). Заходи впливу до власників пам'яток чи уповноважених ними органів (осіб), які не уклали охоронні договори з відповідним органом охорони культурної спадщини, зокрема складання постанов про накладення відповідно до ст. 44 ЗУ «Про охорону культурної спадщини» фінансових санкцій, не застосовувалися. Зазначене $€$ наслідком бездіяльності посадових осіб Мінкультури, відповідальних за цей напрям роботи $[13$, с. 36$]$.

Безумовно, вимога закону дотримуватися законодавства навіть у разі неукладення охоронного договору є вкрай важливою для забезпечення правового режиму використання пам'ятки та земельної ділянки. Однак це не нівелює значення охоронного договору, адже саме у ньому слід детально, 3 урахуванням особливостей конкретної пам'ятки та іiі території визначити зобов'язання сторін. Незважаючи на наявність типової форми такого договору, кожне зобов'язання щодо пам'ятки має бути індивідуальним.

Ще однією особливістю правового режиму земель історико-культурного призначення $€$ дозвільний характер проведення земляних, будівельних чи інших робіт на земельних ділянках історико-культурного призначення. Відповідно до ст. 35 ЗУ «Про охорону культурної спадщини» та ст. 10 ЗУ «Про охорону археологічної спадщини», проведення археологічних розвідок, розкопок, інших земляних робіт на території пам'ятки, охоронюваній археологічній території, у зонах охорони, в історичних ареалах населених місць, а також дослідження решток життєдіяльності людини, що містяться під земною поверхнею, під водою, здійснюються за дозволом, виданим центральним органом виконавчої влади, що реалізує державну політику у сфері охорони культурної спадщини.
Порядок видачі дозволів установлюється Кабінетом Міністрів України. Тривалий час уповноважені органи користуються тимчасовою формою такого дозволу, яка затверджена Наказом Міністерства культури від 24.05.05 № 329. Досі не ведеться робота щодо затвердження постійної форми дозволів. Відсутність у Міністерстві спеціальних бланків дозволів, окремого журналу їх реєстрації призвела до неконтрольованості і непрозорості процесу видачі дозволів. На час проведення аудиту (2018-2019 рр.) Міністерство не володіє інформацією про кількість виданих дозволів [13, с. 11].

Правовий режим земель історико-культурного призначення характеризується й певними особливостями щодо припинення прав на них. Відповідно до п. «Г» ч. 1 ст. 150 ЗК України, землі історико-культурного призначення відносяться до особливо цінних земель. У ч. 2 ст. 150 ЗК України йдеться про те, що припинення права постійного користування такими земельними ділянками на підстави добровільної відмови від користування ними або шляхом їх вилучення здійснюється за погодженням із Верховною Радою України. Видається логічним, що одночасно з відмовою від користування земельною ділянкою історико-культурного призначення користувач має звернутися до відповідного органу у сфері охорони культурної спадщини з питанням про припинення користування пам'яткою.

Окрім того, варто звернути увагу на порядок вилучення (викупу) земель історико-культурного призначення. Дія Закону України «Про відчуження земельних ділянок, інших об'єктів нерухомого майна, що на них розміщені, які перебувають у приватній власності, для суспільних потреб чи з мотивів суспільної необхідності» не поширюється на суспільні відносини, що виникають у разі викупу пам'яток історії та культури, яким загрожує пошкодження або знищення внаслідок дій або бездіяльності їх власника. 
Уважаємо, що викуп земельних ділянок історико-культурного призначення може здійснюватися за рішенням суду як санкція за порушення законодавства про охорону культурної спадщини. Відповідно до ст. 21 ЗУ «Про охорону культурної спадщини» та ст. 352 Цивільного кодексу України, якщо власник пам'ятки не вживе заходів щодо ії збереження, зокрема у зв'язку з неможливістю створення необхідних для цього умов, суд за позовом відповідного органу охорони культурної спадщини може постановити рішення про іiі викуп. Викуплена пам'ятка переходить у власність держави. У такому разі доцільно одночасно пред'являти позов про примусове припинення права власності на земельну ділянку [14, с. 199].

Як слушно зазначає О. Донець, в обох вищезгаданих випадках вилучення (викуп) пам'яток повинно відбуватися у сукупності із земельною ділянкою, на якій розташовано нерухомий об'єкт культурної спадщини, оскільки у такому разі, по-перше, буде зберігатися природне та історичне оточення пам'ятки, а по-друге, унеможливлюється виникнення ситуації, за якої право власності на об'єкт культурної спадщини та на зайняту ним земельну ділянку належать різним суб'єктам, що може призвести у подальшому до певних труднощів використання чи охорони таких об'єктів [12, с. 97].

Аналізуючи Земельний кодекс України та законодавство про охорону культурної спадщини, можна виокремити такі характерні особливості правового режиму земель історико-культурного призначення:

1. Особливості правового режиму земель історико-культурного призначення зумовлені потребою охорони і збереження об'єктів культурної спадщини.

2. Заборона здійснення діяльності, що суперечить їньому цільовому призначенню або може негативно впливати на об'єкт культурної спадщини чи самі землі.

3. Встановлення обмежень щодо набуття окремих об'єктів культурної спадщини, а також певних земельних ділянок історико-культурного призначення у приватну власність.

4. Встановлення охоронних зон, охоронюваних археологічних територій та історичних ареалів місць для забезпечення пам'ятки та дотримання правового режиму земель історико-культурного призначення.

5. Дозвільний характер проведення будь-яких земляних чи будівельних робіт або іншої господарської діяльності на земельних ділянках історико-культурного призначення.

6. Землі історико-культурного призначення $€$ особливо цінними землями і щодо них встановлено особливий порядок припинення прав на них (ст. 150 3К України).

7. Можливість примусового викупу земельної ділянки за рішенням суду, якщо власник пам'ятки не вживає заходів щодо їі збереження.

Особливості правового режиму земель історико-культурного призначення проявляються під час набуття, здійснення та припинення права власності та права користування такими земельними ділянками, управління у сфері використання цих земель та їх правової охорони. На підставі проведеного аналізу можна сформулювати таке визначення правового режиму земель історико-культурного призначення: це встановлений нормами земельного права порядок регулювання відносин у сфері охорони та обмеженого використання земель історико-культурного призначення, що спрямований на збереження об'єктів культурної спадщини, які на них розташовані.

Статтю присвячено дослідженню поняття «правовий режим земель історико-культурного призначення» та місия цієї правової категорії у земельному праві, запропоновано власне визначення правового режиму иієї категорії земель. Автором досліджено чинне законодавство України та наукову літературу в цій сфері. Наведено різні підходи до розумін- 
ня правового режиму як юридичної категорії. Досліджено розуміння правового режиму земель як загалом, так $і$ земель історико-культурного призначення. Окреслено проблематику щодо відмінностей правового режиму земель історико-культурного призначення, охоронних зон, історичних ареалів міст та охоронюванuх археологічних територій. Окрім того, автор підтверджує зв'язок між правовим режимом пам'яток та земельними ділянками, на яких вони розташовуються. Саме пам'ятка культурної спадщини є тим об'єктом, щьо зумовлюе наявність правового режиму земель історико-культурного призначення. Наголошується, що особливості правового режиму земель історико-культурного призначення зумовлені потребою охорони і збереження об'єктів культурної спадщини. Проаналізовано розподіл повноважень у сфері охорони культурної спадицни та ї територій, що належать Кабінету Міністрів України, Міністерству культури та інформаційної політики Украӥни, а також місиевим органам охорони культурної спадщини. Проаналізовано обмеження щодо набуття об'єктів культурної спадщини, а також певних земельних ділянок історико-культурного призначення у приватну власність. Автор звертає увагу на важливість укладення охоронних договорів, визначаючи у них обов'язки власників та перелік робіт, що необхідно здійснити. Досліджено питання дозволів на проведення будь-яких земляних чи будівельних робіт або іншої господарської діяльності на земельних ділянках історико-культурного призначення. Проаналізовано засади припинення прав на земельні ділянки історико-культурного призначення та віоповідальності за порушення у ї використанні чи інші порушення законодавства про охорону культурної спадщини.

Ключові слова: правовий режим земель, правовий режим земель істо- рико-культурного призначення, об'єкти культурної спадщини.

Hulkevych 0 . Legal regime of lands of historical and cultural purpose

The article is devoted to the study of the concept of the legal regime of historical and cultural lands and its importance in land law of Ukraine, the definition of the legal regime of this category of land is proposed. The author studies the current legislation of Ukraine and the doctrine in this area. Different approaches to understanding the legal regime as a legal category are presented. The understanding of the legal regime of lands both in general and lands of historical and cultural purpose is studied. The author outlines the problems of differences in the legal regime of historical and cultural lands, protected areas, historical areas of cities and protected archaeological sites. In addition, the author confirms the connection between the legal regime of monuments and the land on which they are located. The monument is the object that determines the existence of the legal regime of historical and cultural lands. It is emphasized that the peculiarities of the legal regime of historical and cultural lands are due to the need to protect and preserve cultural heritage sites. The author analyzes the distribution of powers in the field of protection of cultural heritage and its territories belonging to the Cabinet of Ministers of Ukraine, the Ministry of Culture and Information Policy of Ukraine, as well as local bodies for the protection of cultural heritage. The author analyzes the restrictions on the question of private ownership on cultural heritage and its territoris. The author draws attention to the importance of concluding protection agreements, defining the responsibilities of the owners and the list of works that need to be done by them. The issue of permits for any type of works or other activities on land plots of historical and cultural significance has been studied. 
The principles of termination of rights to land plots of historical and cultural purpose and liability for violations in their use or other violations of the legislation on protection of cultural heritage are analyzed.

Key words: legal regime of lands, legal regime of lands of historical and cultural purpose, cultural heritage.

\section{Література}

1. Концепція державної політики реформування сфери охорони нерухомої культурної спадщцини. URL : http:// mincult.kmu. gov.ua/control/uk/publish/article?art_ $i d=245358162 \&$ cat_id $=244993460 \quad$ (dama звернення: 22.05.2020).

2. Заморська Л.І. Нормативність права як засіб оптимізаиіі правового режиму: теоретичний аналіз. Право $i$ суспільство. 2011. № 4. C. 18-21. URL : http:// nbuv.gov.ua/UJRN / Pis_2011_4_6.

3. Шамсумова Э.Ф. Правовые режимь: теоретический аспект : автореф. дис. ... канд. юрид. наук: 12.00.01. Екатеринбург, 2001. 24 c.

4. Томаш Л.В. Правовий режим: поняття та ознаки. Науковий вісник Чернівеиького наиіонального університету ім. Юрія Федьковича. 2005. № 282. С. 20-27.

5. Титова Н.I. Землі сільськогосподарського призначення: права громадян України : навчальний посібник / за ред. H.I. Титової. Львів : ПАІС, 2005. 368 c.

6. Андрейцев B.I. Земельне право і законодавство суверенної України: актуальні проблеми практичної теорії. Київ : Знання, 2005. $445 \mathrm{c}$.

7. Семчик B.I. Правовий режим земель сільськогосподарського призначення. Земельне право : академічний курс / за ред. В.І. Семчика, П.Ф. Кулинича. Київ : Ін Юpe, 2001. С. 260-292.

8. Мірошниченко А.М., Марусенко P.I. Науково-практичний коментар до Земельного кодексу України ; 2-е вид., змін. $і$ доп. Київ : Aлерта ; КНТ, ЦУЛ, 2009. 507 c.

9. Бондар Л.О. Правовий режим земель історико-культурного призначення. Земельне право України: підручник / за ред. O.O. Погрібного та I.I. Каракаша ; вид. 2-е, перероб. $і$ доп. Київ: Iстина, 2009. С. 393-411.

10. Бевз О.В. Правовий режим земель історико-культурного призначення в Украіні (історичні ареали населених місиь) : дис. ... канд. юрид. наук : 12.00.06. Київ, 2012. 212 c.
11.Бондар Л.О. Правовий режим земель історико-культурного призначення. Земельне право України : підручник / за ред. О.О. Погрібного та I.I. Каракаша ; вид. 2-е, перероб. $i$ доп. Київ : Iстина, 2009. C. 393-411.

12. Донещь О.В. Правовий режим земель історико-культурного призначення дис. ... канд. юрид. наук : 12.00.06. Харків, 2010. $216 \mathrm{c}$.

13. Звіт про результати аудиту ефективності використання коштів державного бюджету, виділених Міністерству культури Украӥни на збереження історико-культурної та архітектурної спадщини в національних $i$ державних заповідниках, здійснення заходів з охорони культурної спадщини, паспортизація, інвентаризація та реставрація пам'яток архітектури, культури та світової спадщини ЮНЕСКО : Рішення Рахункової палати від 28.05.2019 № 12-4. URL : https://rp.gov.ua/upload-files / Activity / Collegium / 2019/12-4_2019/ Zvit_12-4_2019.pdf.

14. Елісєева О.В. Припинення права приватної власності на земельну ділянку за законодавством України : дис. ... канд. юрид. наук: 12.00.06. Київ, 2006. 240 c.

15. Земельний кодекс України Закон України від 25.10.2001 № 2768 III. URL : http://zakon5.rada.gov.ua/laws / show/2768-14 (дата звернення: 14.05.20).

16. Порядок визначення категорій пам'яток : Постанова Кабінету Міністрів Украӥни від 22 травня 2019 р. № 452. URL : https: / / zakon.rada.gov.ua/laws / show / 452-2019$\%$ D0\% BF (дата звернення: 14.05.20).

17. Про Державний земельний кадастр : Закон України від 07.07.2011 № 3613-VI. URL : https://zakon.rada.gov.ua/laws / show/3613-17 (дата звернення: 14.05.20).

18. Про охорону археологічної спадщини : Закон України від 18.03.2004 № 1626IV. URL : https: / / zakon.rada.gov.ua/laws / show/1626-15 (дата звернення: 14.05.20).

19. Про охорону культурної спадщини : Закон України від 08.06.2000 № 1805-III. URL : http://zakon5.rada.gov.ua/laws / show/1805-14 (дата звернення: 14.05.20).

20. Про Перелік пам'яток культурної спадщини, що не підлягають приватизації : Закон України від 23.09.2008 № 574-VI. URL : https: / / zakon.rada.gov.ua/laws / show/574-17 (дата звернення: 14.05.20).

21. Цивільний кодекс України: Закон України від 16.01.2003 № 435-IV. URL : https:/ / zakon.rada.gov.ua/laws/show/435-15 (Jama звернення: 14.05.20). 